\title{
MACROCYTIC ANEMIA IN PREGNANT WOMEN WITH VITAMIN B DEFICIENCY 1
}

\author{
By KATHARINE O'SHEA ELSOM ${ }^{2}$ WITH THE TECHNICAL ASSISTANCE OF \\ ALBERT B. SAMPLE \\ (From the Gastro-Intestinal Section of the Medical Clinic, Hospital of the University of \\ Pennsylvania, Philadelphia)
}

(Received for publication August 17, 1936)

Recent observations of sprue (1), pernicious anemia (2), tropical macrocytic anemia (3) and the pernicious anemia of pregnancy (4) have led to the hypothesis that a dietary deficiency of vita$\min \mathrm{B}^{3}$ or some closely allied substance is responsible both for the anemia and for the clinical manifestations of these diseases. Animal experiments designed to test this hypothesis $(5,6,7)$ have yielded results which vary with the species of animal employed. This and the fact that macrocytic anemia does not occur in animals as a spontaneous entity constitute limitations which made it seem desirable to study the problem in human beings. The occurrence in pregnancy of a syndrome which resembles pernicious anemia and the other macrocytic anemias in every important respect except that it is temporary suggested that there may develop during that period a temporary deficiency of factors necessary to prevent macrocytic anemia. If the assumption is correct that vitamin B is the responsible factor one would expect to encounter a high percentage of anemia of this type in women who, by force of circumstances, were taking a diet during pregnancy which was deficient in vitamin B. Pregnant patients taking poor diets have been observed by Strauss and Castle (8) to develop macrocytic anemia late in pregnancy. The subjects of that investigation consumed diets deficient in many substances, however, and it was impossible to be certain whether one alone of the missing factors was responsible for the development of the anemia. It seemed desirable, therefore, to determine whether pregnant women such as those

\footnotetext{
1 Aided by a donation from Mr. Samuel S. Fels and by a grant from the Faculty Research Committee of the University of Pennsylvania.

2 Justice M. Thompson Fellow in Gastro-enterology.

3 The term vitamin $B$ as used in this paper includes all members of the vitamin $B$ complex. Individual members are referred to as vitamin $B_{1}, B_{2}$, etc.
}

studied by Strauss and Castle would develop this form of anemia when their habitually inadequate diet was supplemented to bring it to the level of full caloric requirements and otherwise adequate conditions but without any attempt to supply deficiency of vitamin B. It may be noted that these patients admitted to an obstetrical clinic were subsisting on a diet deficient in calories as well as vitamins. Any resulting anemia under these circumstances may be attributable to general nutritional deficiency or to vitamin inadequacy. It was the purpose of this study to determine which factor is significant. Every other known essential was therefore added to the diet and such amounts of vitamin B as had been taken in the previous diet continued to be given but no attempt was made to increase this factor, the importance or unimportance of taking which was the object of the study. By careful clinical observation the early signs of vitamin $B$ deficiency previously described in a report from this Clinic (9) were sought and when detected were promptly relieved by the administration of brewer's yeast or liver extract. The present communication is a report of studies made chiefly upon the blood, gastric secretion and clinical manifestations of these women from the 4th month of pregnancy to term.

\section{METHODS OF STUDY}

The subjects of the study were selected from among the patients attending the Outpatient Maternity Clinics of this and the Pennsylvania Lying-In Hospitals. Each subject was examined every 10 to 14 days at which time a detailed record was made of symptoms and physical observations. Blood was drawn without stasis from an antecubital vein.

Seven clinical phenomena, manifestations of vitamin B deficiency, recognizable from previous study (9) were watched for in particular. The 
changes were: alterations of the tongue, gastrointestinal symptoms, paresthesias, impaired vibratory sense, susceptibility to fatigue, edema and tachycardia. The term "deficiency index" has been used in the text to denote the number of these phenomena manifested at any given time by each individual. The deficiency index ranges from 0 to 7 .

The acuity of perception of vibration was determined with a $\mathrm{C}$ tuning fork (128 vibrations per second). A standard of reference was obtained from normal persons who perceived a sense of vibration for 20 to 30 seconds when the fork, vibrating at maximal intensity, was placed over were made in duplicate from smears of blood stained immediately with brilliant cresyl blue, 1000 cells being counted. Morphological changes in the cells were observed from smears of blood prepared with Wright's stain. The infants were examined and erythrocyte counts and hemoglobin estimations were made at birth and at 1,3 and 9 months of age.

RESULTS

\section{Dietary requirements}

The 11 subjects of this report took diets so constant that the composition, the caloric and the protein values could be estimated with accuracy.

TABLE I

Chart showing articles composing the diets of Group I

\begin{tabular}{|c|c|c|c|}
\hline $\begin{array}{l}\text { Vegetables } \\
\text { Beans (kidney) } \\
\text { Potatoes } \\
\text { Turnips } \\
\text { Corn (canned) } \\
\text { Beets } \\
\text { Spinach } \\
\text { Onions } \\
\text { Cabbage } \\
\text { Rutabaga } \\
\text { Carrots }\end{array}$ & $\begin{array}{l}\quad \text { Cereals and starches } \\
\text { Cornmeal } \\
\text { Cream of wheat } \\
\text { Cornflakes } \\
\text { Rice } \\
\text { Macaroni } \\
\text { Spaghetti }\end{array}$ & $\begin{array}{l}\text { Pastry and desserts } \\
\text { Bread } \\
\text { Crackers } \\
\begin{array}{l}\text { Cake } \\
\text { Pie: apple } \\
\text { pear }\end{array} \\
\left.\begin{array}{l}\text { Puddings: cornstarch } \\
\text { rice } \\
\text { gelatine }\end{array}\right\} \begin{array}{l}\text { without } \\
\text { milk }\end{array} \\
\begin{array}{l}\text { Candies } \\
\text { Jellies }\end{array}\end{array}$ & $\begin{array}{l}\text { Meat } \\
\text { Veal } \\
\text { Lamb } \\
\text { Corned beef } \\
\text { Frankfurters }\end{array}$ \\
\hline $\begin{array}{l}\text { Fats } \\
\text { Butter } \\
\text { Mayonnaise } \\
\text { Lard }\end{array}$ & $\begin{array}{l}\quad \text { Seasonings, etc. } \\
\text { Chocolate } \\
\text { Cinnamon } \\
\text { Molasses } \\
\text { Syrup } \\
\text { Honey, salt, etc. }\end{array}$ & $\begin{array}{l}\text { Fruit } \\
\text { Apples } \\
\text { Pears } \\
\text { Grapes } \\
\text { Cocoanut }\end{array}$ & $\begin{array}{l}\text { Beverages } \\
\text { Tea } \\
\text { Coffee } \\
\text { Grape juice } \\
\text { Gingerale }\end{array}$ \\
\hline
\end{tabular}

any bony prominence of the lower extremities. Electrocardiograms and orthodiagrams were made several times, as were also gastric analyses in which the rate and the acid content of the fasting secretion and the acid response to $50 \mathrm{cc}$. of 7 per cent alcohol were determined. Titrations of acid were carried out in the usual way with 0.1 normal $\mathrm{NaOH}$, using Topfer's reagent and phenolphthalein as indicators.

Erythrocyte counts were made in triplicate, using pipettes certified by the U. S. Bureau of Standards. Hemoglobin values were determined by the method of Stadie (10) which permits accurate determination of hemoglobin concentration to within 0.3 gram per $100 \mathrm{cc}$. of blood. Hematocrit determinations were made in duplicate using Wintrobe tubes. Mean corpuscular volume and mean corpuscular hemoglobin were calculated in the usual fashion (11). Reticulocyte counts
Eight subjects hereafter called Group I consumed throughout the period of observation a diet composed of the articles shown in Table I. These foods were taken in amounts which supplied approximately 50 calories and 1.5 grams of protein per kilogram of body weight per day. The vitamin B:calorie ratio of this diet was approximately 1.66 . The vitamin B per calorie requirement of these subjects at the beginning of the observation, calculated from Cowgill's ${ }^{4}$ formula (12), averaged 1.5 (Table II). Since the caloric intake of these women remained essentially constant throughout observation, their theoretical re-

$$
4 \quad \frac{\text { Vitamin } B}{\text { Calories }}=.0000284 \text { Weight grams. }
$$

Although the figure obtained by this formula of Cowgill's applies strictly to vitamin $B_{1}$, it is used here as an index of the concentration of other vitamin B fractions since, as far as is known, other fractions were present in the diet in approximately the same concentration as $B_{1}$. 
TABLE II

The theoretical requirement of vitamin $B$ per calorie, * the intake of vitamin $B$ per calorie ** and the deficiency index of subjects of Group I at various times during pregnancy

\begin{tabular}{|c|c|c|c|c|c|c|c|c|c|c|}
\hline \multirow{2}{*}{$\begin{array}{c}\text { Sub- } \\
\text { ject } \\
\text { num- } \\
\text { ber }\end{array}$} & \multicolumn{3}{|c|}{$\begin{array}{l}\text { Beginning of period } \\
\text { of obeervation }\end{array}$} & \multicolumn{3}{|c|}{$\begin{array}{l}\text { Appearance of definite } \\
\text { clinical phenomena }\end{array}$} & \multicolumn{4}{|c|}{$\begin{array}{l}\text { Final eramination after } \\
\text { administration of therapytt }\end{array}$} \\
\hline & $\begin{array}{c}\text { Days } \\
\text { of } \\
\text { preg- } \\
\text { nancy }\end{array}$ & $\begin{array}{c}\text { Vitamin } \\
\text { B: } \\
\text { calorie } \\
\text { ratio } \\
\text { required }\end{array}$ & $\begin{array}{l}\text { D. } \\
\text { I. }\end{array}$ & $\begin{array}{c}\text { Days } \\
\text { of } \\
\text { preg- } \\
\text { nancy }\end{array}$ & $\begin{array}{c}\text { Vitamin } \\
\text { B: } \\
\text { calorie } \\
\text { ratio } \\
\text { required }\end{array}$ & \begin{tabular}{|l} 
D. \\
I.
\end{tabular} & $\begin{array}{c}\text { Days } \\
\text { of } \\
\text { preg- } \\
\text { nancy }\end{array}$ & $\begin{array}{l}\text { Vitamin } \\
\text { B: } \\
\text { calorie } \\
\text { ratio } \\
\text { required }\end{array}$ & $\begin{array}{l}\text { D. } \\
\text { I. } \dagger\end{array}$ & $\begin{array}{l}\text { Days } \\
\text { of } \\
\text { ther- } \\
\text { apy }\end{array}$ \\
\hline $\begin{array}{l}1 \\
2 \\
3 \\
4 \\
5 \\
6 \\
6 \\
7 \\
8\end{array}$ & $\begin{array}{r}82 \\
102 \\
112 \\
96 \\
107 \\
96 \\
62 \\
138\end{array}$ & $\begin{array}{l}1.8 \\
1.5 \\
1.5 \\
1.3 \\
1.6 \\
1.5 \\
1.4 \\
1.8\end{array}$ & $\begin{array}{l}0 \\
0 \\
0 \\
0 \\
0 \\
0 \\
0 \\
0\end{array}$ & $\begin{array}{l}236 \\
2364 \\
234 \\
233 \\
249 \\
249 \\
232 \\
265\end{array}$ & $\begin{array}{l}2.0 \\
1.6 \\
1.7 \\
1.6 \\
1.9 \\
1.8 \\
1.7 \\
2.2\end{array}$ & \begin{tabular}{|l|}
7 \\
4 \\
6 \\
5 \\
5 \\
3 \\
7 \\
6 \\
\end{tabular} & $\begin{array}{l}271 \\
280 \\
269 \\
277 \\
277 \\
277 \\
280 \\
279\end{array}$ & $\begin{array}{l}2.1 \\
1.6 \\
1.7 \\
1.6 \\
2.0 \\
1.8 \\
1.8 \\
2.2\end{array}$ & $\begin{array}{l}2 \\
2 \\
1 \\
1 \\
3 \\
0 \\
1 \\
1\end{array}$ & $\begin{array}{l}35 \\
16 \\
35 \\
44 \\
28 \\
28 \\
48 \\
14\end{array}$ \\
\hline $\begin{array}{c}\text { Aver- } \\
\text { age }\end{array}$ & 99 & 1.5 & 0 & 245 & 1.8 & 5 & 276 & 1.9 & 1 & 31 \\
\hline
\end{tabular}

* From the Cowgill formula (12): $\frac{\text { Vitamin B }}{\text { Calories }}=.0000284$

Weight grams.

** Vitamin B per calorie of diet $=1.66$.

$\dagger$ D. $I .=$ deficiency index.

t† Vitamin B per calorie of diet +therapy $=6.55$.

quirement for vitamin $B$ increased in proportion to the increase in weight. On the average, at the 245th day of pregnancy this theoretical requirement exceeded the vitamin B per calorie content of the diet. At approximately this same time, also, definite clinical evidence of vitamin B deficiency was observed and the characteristic blood changes to be described were noticed. As soon as these changes became clearly recognizable 21 grams of brewer's yeast ${ }^{5}$ were administered orally or $2 \mathrm{cc}$. of liver extract ${ }^{6}$ were given intramuscularly daily until the termination of pregnancy. These materials increased the vitamin B per calorie intake to 6.55 , far exceeding the vitamin $B$ requirement. Following this procedure all clinical evidence of deficiency disappeared and blood values returned toward normal.

Group II includes 3 subjects who habitually consumed a normal varied diet, having an average vitamin B : calorie ratio of 2.8 (Table III). The vitamin $\mathrm{B}$ per calorie requirement of this group at no time exceeded the vitamin $B$ content of the diet and no definite clinical evidence of deficiency or characteristic alterations in the blood were encountered.

5 This material was kindly supplied as "Brewer's Yeast-Harris" through the courtesy of the Harris Laboratories, Tuckahoe, N. Y.

6 Liver extract no. 343 (Lilly) for intramuscular use.
TABLE III

The theoretical requirement of vitamin $B$ per calorie, the intake of vitamin $B$ per calorie and the deficiency index of subjects of Group II at various times during pregnancy

\begin{tabular}{|c|c|c|c|c|c|c|c|c|c|c|}
\hline \multirow{2}{*}{$\begin{array}{c}\text { Sub- } \\
\text { ject } \\
\text { num- } \\
\text { ber }\end{array}$} & \multirow{2}{*}{$\begin{array}{l}\text { Vitamin } \\
\text { B: } \\
\text { calorie } \\
\text { ratio } \\
\text { of diet }\end{array}$} & \multicolumn{3}{|c|}{$\begin{array}{l}\text { Beginning of period } \\
\text { of obeervation }\end{array}$} & \multicolumn{3}{|c|}{$\begin{array}{l}\text { 8th to 9th } \\
\text { month }\end{array}$} & \multicolumn{3}{|c|}{$\begin{array}{c}\text { Final } \\
\text { examination }\end{array}$} \\
\hline & & $\begin{array}{c}\text { Days } \\
\text { of } \\
\text { preg- } \\
\text { nancy }\end{array}$ & $\begin{array}{l}\text { Vitamin } \\
\text { B: } \\
\text { calorie } \\
\text { ratio } \\
\text { required }\end{array}$ & D. & $\begin{array}{c}\text { Days } \\
\text { of } \\
\text { preg- } \\
\text { nancy }\end{array}$ & $\begin{array}{c}\text { Vitamin } \\
\text { B: } \\
\text { calorie } \\
\text { ratio } \\
\text { required }\end{array}$ & D. & $\begin{array}{c}\text { Days } \\
\text { of } \\
\text { preg- } \\
\text { nancy }\end{array}$ & $\begin{array}{l}\text { Vitamin } \\
\text { B: } \\
\text { calorie } \\
\text { ratio } \\
\text { required }\end{array}$ & D. \\
\hline $\begin{array}{l}1 \\
2 \\
3\end{array}$ & $\begin{array}{l}3.4 \\
2.5 \\
2.3^{*}\end{array}$ & $\begin{array}{r}59 \\
125 \\
120\end{array}$ & $\begin{array}{l}1.3 \\
1.5 \\
1.5\end{array}$ & $\begin{array}{l}0 \\
0 \\
0\end{array}$ & $\begin{array}{l}220 \\
224 \\
246\end{array}$ & $\begin{array}{l}1.5 \\
1.7 \\
1.9\end{array}$ & \begin{tabular}{|l|}
0 \\
0 \\
3
\end{tabular} & $\begin{array}{l}273 \\
273 \\
267\end{array}$ & $\begin{array}{l}1.5 \\
1.8 \\
1.9\end{array}$ & $\begin{array}{l}\mathbf{0} \\
\mathbf{0} \\
\mathbf{0}\end{array}$ \\
\hline $\begin{array}{c}\text { Aver- } \\
\text { age }\end{array}$ & 2.8 & 101 & 1.4 & 0 & 230 & 1.7 & 1 & 271 & 1.7 & 0 \\
\hline
\end{tabular}

* 21 grams of brewer's yeast administered to this subject from the $253 \mathrm{~d}$ to the 267 th day of pregnancy increased to 10.2 the Vitamin B: calorie ratio of her diet during that time.

Adequate intake of vitamins $\mathrm{A}, \mathrm{C}$ and $\mathrm{D}$ and of iron, in addition to adequate protein and total calorie intake, was assured for both groups by the daily addition to the diet of $150 \mathrm{cc}$. of orange juice, one tablet of halibut liver oil concentrate with viosterol ${ }^{7}$ and 6 grains of ferrous sulphate. ${ }^{8}$

\section{Changes in the blood}

The following characteristic changes in the blood developed during pregnancy in all of the subjects of Group I: decrease in the number of red blood cells, increase in mean cell volume and in mean cell hemoglobin, macrocytosis, reticulocytosis, and the appearance of many polychromatic cells, poikilocytes and young white cells. These changes were greatest at the time that the diet became theoretically inadequate in vitamin $B$ and when the clinical manifestations were definite. The maximal changes in blood values of the subjects of this group are given in Table IV. The average number of red blood cells decreased 18 per cent and the mean cell volume increased 21 per cent. There was a slight fall in hemoglobin early in the period of observation which did not equal the fall in red cells, so that the mean cell hemoglobin increased on the average 14 per cent. The mean cell hemoglobin increased further in certain subjects later in the

7 Obtained from E. R. Squibb and Sons.

8 Feosol was kindly supplied by the Smith, Kline and French Co., Phila. 
period of observation but before vitamin $B$ therapy was begun. This was due to a return toward normal of the total hemoglobin values without in-

TABLE IV

Maximal change in blood values of subjects of Group I

\begin{tabular}{|c|c|c|c|c|c|c|c|c|c|c|}
\hline \multirow{2}{*}{$\begin{array}{l}\text { Sub- } \\
\text { ject } \\
\text { num- } \\
\text { ber }\end{array}$} & \multicolumn{5}{|c|}{$\begin{array}{l}\text { Initial blood } \\
\text { values }\end{array}$} & \multicolumn{5}{|c|}{$\begin{array}{l}\text { Blood values at time of } \\
\text { greatest anemia }\end{array}$} \\
\hline & R. B. & Hgb. & $\begin{array}{l}\text { Hema- } \\
\text { tocrit }\end{array}$ & M. & $\mid \begin{array}{c}\text { M. C. } \\
\text { H.gb. }\end{array}$ & R. B. & Hgb. & $\begin{array}{l}\text { Hema- } \\
\text { tocrit }\end{array}$ & $\mathbf{M}_{\mathbf{V} .} \mathbf{C .}$ & $\begin{array}{l}\text { M.C. } \\
\text { Hgb. }\end{array}$ \\
\hline $\begin{array}{l}1 \\
2 \\
3 \\
4 \\
5 \\
6 \\
7 \\
8\end{array}$ & \begin{tabular}{|l|} 
mil \\
lions \\
\\
3.65 \\
4.28 \\
4.74 \\
3.33 \\
3.90 \\
3.79 \\
4.00 \\
3.76
\end{tabular} & \begin{tabular}{|c|} 
grams \\
per \\
100 \\
$c c$. \\
13.0 \\
13.1 \\
13.2 \\
10.9 \\
12.6 \\
12.8 \\
13.5 \\
13.4 \\
\end{tabular} & \begin{tabular}{|c|} 
sol \\
umes \\
per \\
cent \\
37.9 \\
40.4 \\
41.2 \\
35.6 \\
38.2 \\
39.2 \\
39.7 \\
40.1
\end{tabular} & $\begin{array}{r}\mu^{8} \\
\\
104 \\
94 \\
93 \\
107 \\
98 \\
103 \\
99 \\
107\end{array}$ & $\begin{array}{c}\text { grams } \\
\times \\
10^{-12} \\
35.6 \\
30.7 \\
27.8 \\
32.6 \\
32.2 \\
33.8 \\
33.8 \\
35.5\end{array}$ & 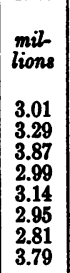 & $\begin{array}{c}\text { grams } \\
\text { per } \\
100 \\
c c . \\
11.3 \\
11.9 \\
14.0 \\
11.6 \\
12.3 \\
11.0 \\
11.3 \\
12.9\end{array}$ & $\begin{array}{c}\text { ool- } \\
\text { umes } \\
\text { per } \\
\text { cent } \\
37.4 \\
38.9 \\
45.3 \\
38.3 \\
38.1 \\
35.6 \\
34.7 \\
42.2\end{array}$ & $\begin{array}{l}\mu^{3} \\
\\
124 \\
118 \\
117 \\
128 \\
121 \\
121 \\
124 \\
111\end{array}$ & 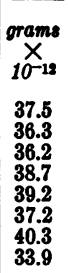 \\
\hline $\begin{array}{c}\text { Aver- } \\
\text { gge }\end{array}$ & 3.93 & 12.8 & 39.0 & 100 & 32.7 & 3.23 & 12.0 & 38.8 & 121 & 37.4 \\
\hline $\begin{array}{c}\text { Per } \\
\text { cent } \\
\text { of } \\
\text { change }\end{array}$ & & & & & & -18.0 & -6.0 & -0.5 & +21.0 & +14.0 \\
\hline
\end{tabular}

* M. C. V. = Mean corpuscular volume.

† M. C. Hgb. = Mean corpuscular hemoglobin. crease in the number of red cells. Alterations in the blood first appeared 1 to 3 months after observations were begun, concomitant with the first appearance of clinical evidence of deficiency (Figures 1,2 and 3). These changes were at first slight, becoming clearly recognizable only later at which time therapy was begun. The percentage of reticulocytes gradually increased until the administration of vitamin B was commenced, the average maximum being 3.5 per cent. Distinct variation in size of the red cells was noticeable at this time (Figures 4 and 5). Pale staining macrocytes were frequent, as were poikilocytes, polychromatic cells and immature white cells.

\section{Clinical observations}

The symptoms and physical signs which appeared in the subjects of Group I during the period of observation were characteristic (Table V). Alterations in the tongue and neurological changes occurred in all subjects, the other characteristic signs being less constant. The intensity

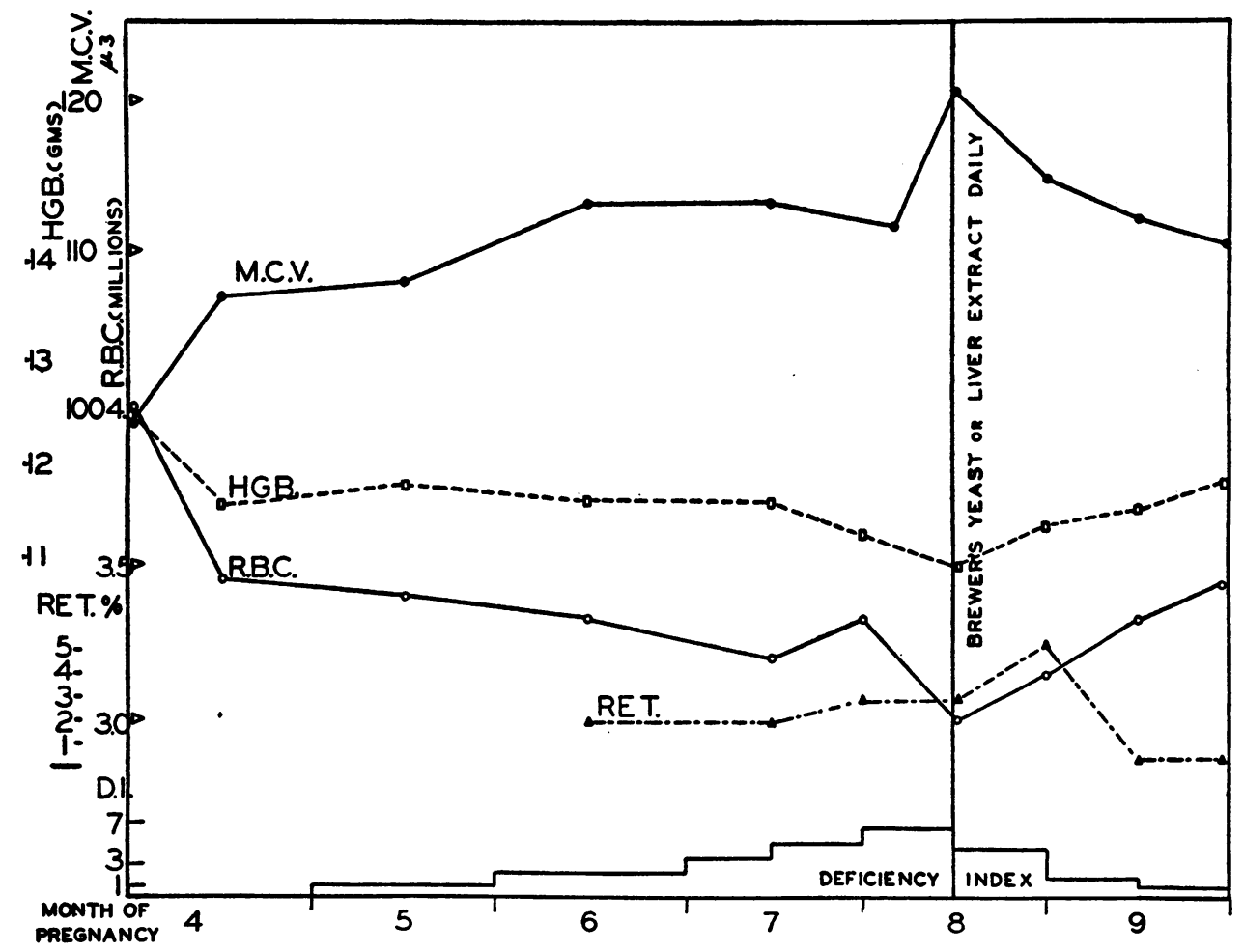

Fig. 1. Changes in Average Blood Values of 3 Subjects of Group I Who Received Therapy During the 8th and 9th Months of Pregnancy.

Ret. $=$ Reticulocytes. M. C. V. $=$ Mean corpuscular volume. D. I. = Deficiency Index. 


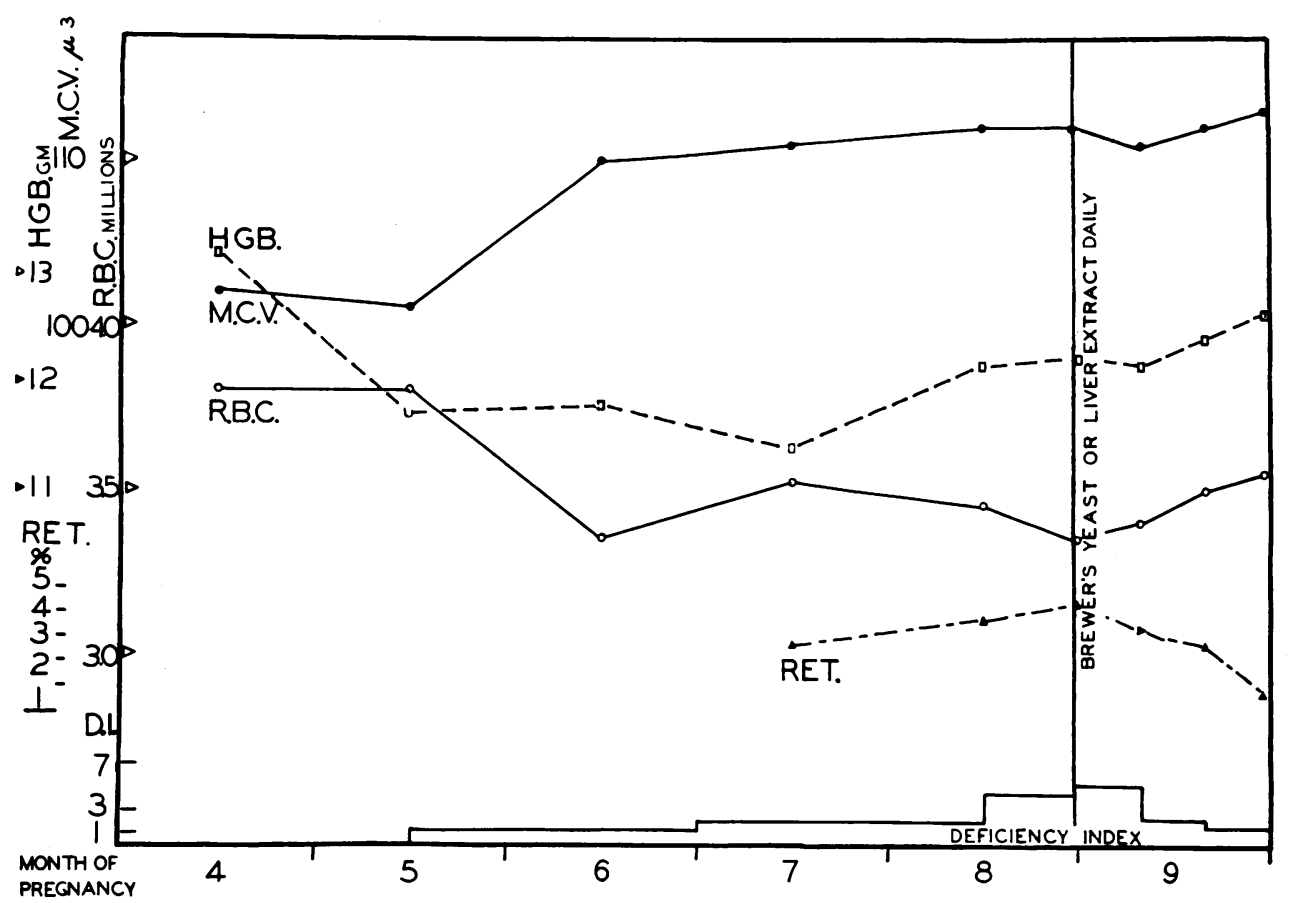

Fig. 2. Changes in Arerage Blood Values of 2 Subjects of Group I Who Received Therapy During the 9th MoNth of Pregnancy.

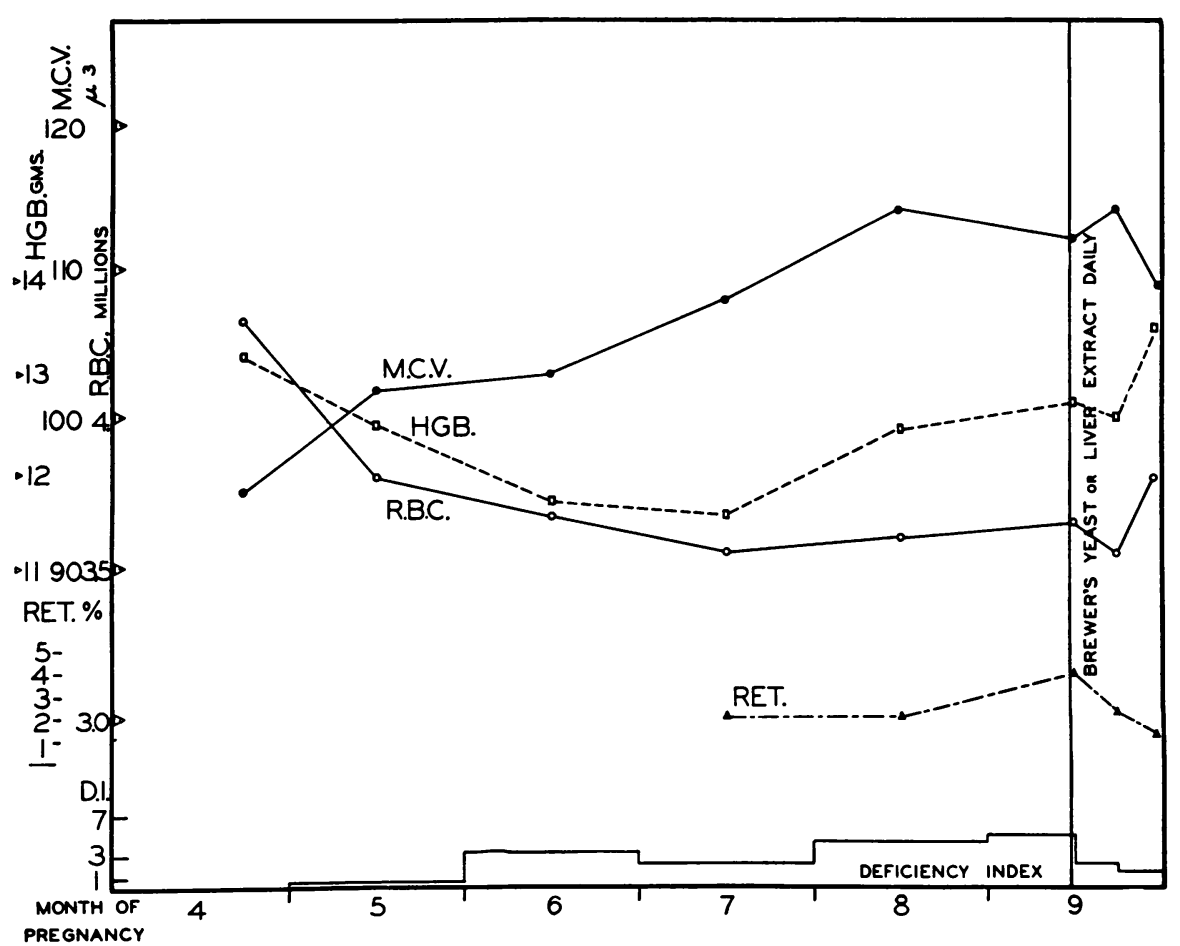

Fig. 3. Changes in Average Blood Values of 2 Subjects of Grovy I Who Received Therapy During the last 2 Weeks of Pregnancy. 
TABLE $V$

Clinical observations on subjects of Group I: Their incidence, and time of relief following vitamin $B$ therapy

\begin{tabular}{|c|c|c|}
\hline Clinical observations & $\begin{array}{l}\text { Num- } \\
\text { ber of } \\
\text { sub- } \\
\text { jects } \\
\text { af- } \\
\text { fected }\end{array}$ & $\begin{array}{c}\text { Average } \\
\text { time } \\
\text { of } \\
\text { relief } \\
\text { after } \\
\text { therapy }\end{array}$ \\
\hline 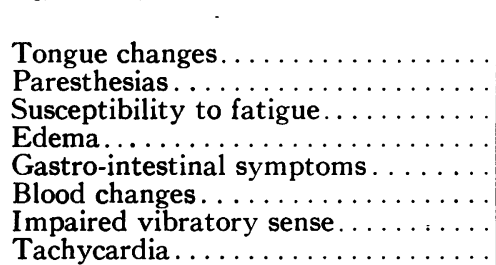 & $\begin{array}{l}8 \\
7 \\
6 \\
5 \\
5 \\
8 \\
8 \\
4\end{array}$ & $\begin{array}{l}\text { days of therapy } \\
14\left(5-39^{*}\right) \\
18(9-28) \\
14(9-25) \\
26(9-35) \\
17(7-25) \\
7 \dagger(5-14) \\
24(17-35) \\
19(9-25)\end{array}$ \\
\hline
\end{tabular}

* Figures in parentheses represent maximum variations from the average.

$\dagger$ This figure represents time of first definite change in reticulocyte count.

of the manifestations varied among the individuals (for details see protocols), but once present each symptom or physical sign, at first so mild as to escape casual observation, persisted, usually increasing until therapy was begun (Figures 1, 2 and 3 ). The first changes noticed were those in the tongue. These changes started at the edges of the tongue and later spread over the dorsum; they varied from slight reddening, with or without loss of papillae, to ulceration. The ulcers were shallow, at first discrete, later coalescing, with smooth red bases and white aphthoid edges. They were painful, and in one of the subjects were associated with ulcers of the lips. Changes in the tongue always preceded gastro-intestinal symptoms and occurred at approximately the time when the women first complained of being easily fatigued. The earliest gastro-intestinal symptom was anorexia, followed by heartburn or a sense of constant fullness in the epigastrium. Dysphagia was present in 2 subjects. Nausea and vomiting were rare. Constipation was the rule, but abdominal cramps with intermittent diarrhea occurred twice.

Edema, extensive in one instance, was manifest in most subjects as slight pitting on pressure over the tibiae. An average increase in the pulse rate of 16 per minute occurred. The cardiac rate frequently was unstable. Prominence of the pulmonary artery was seen on orthodiagraphy in one-third of the subjects. No characteristic change in resting blood pressure was observed.

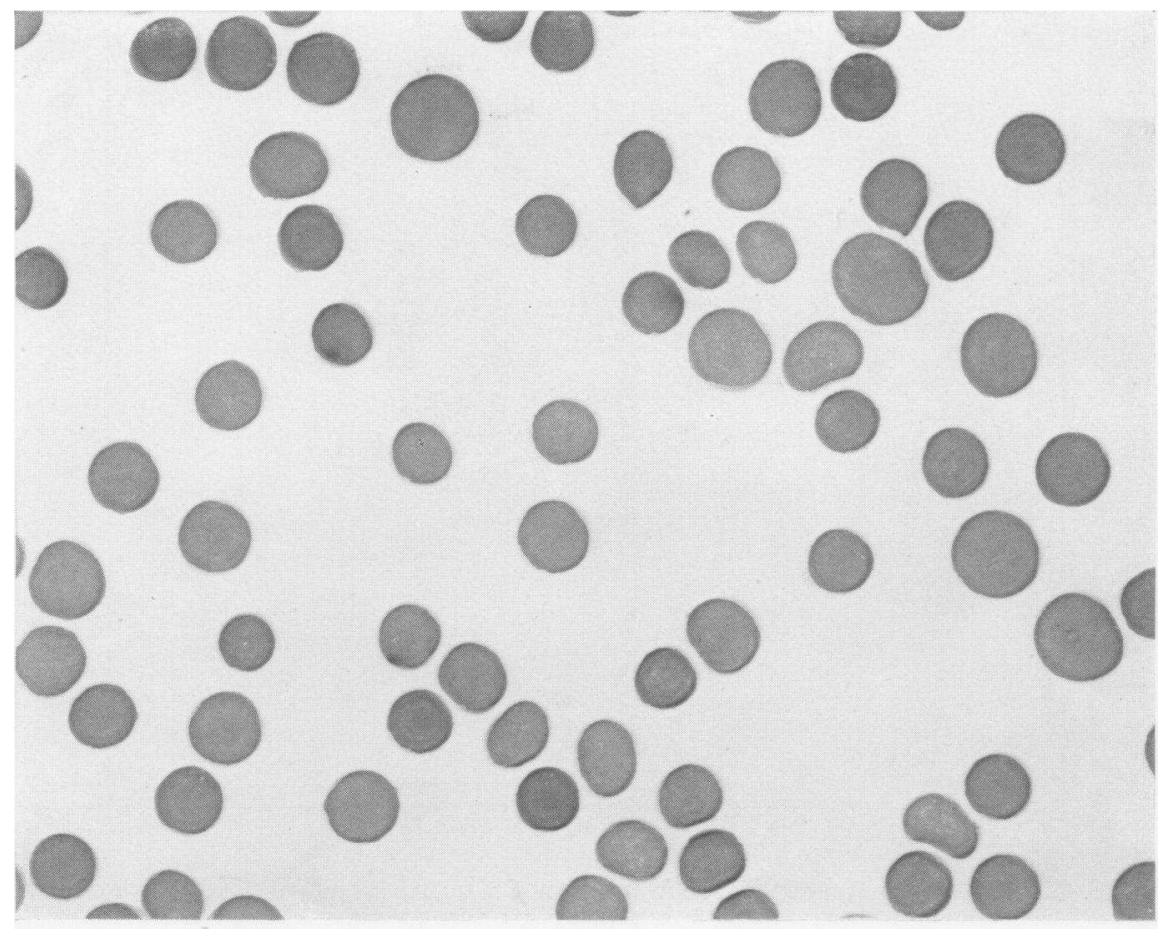

Fig. 4. Photomicrograph of the Blood of Subject Number 7 at the Time of Maximal Anemia. $\times 774$. Wright's Stain. 


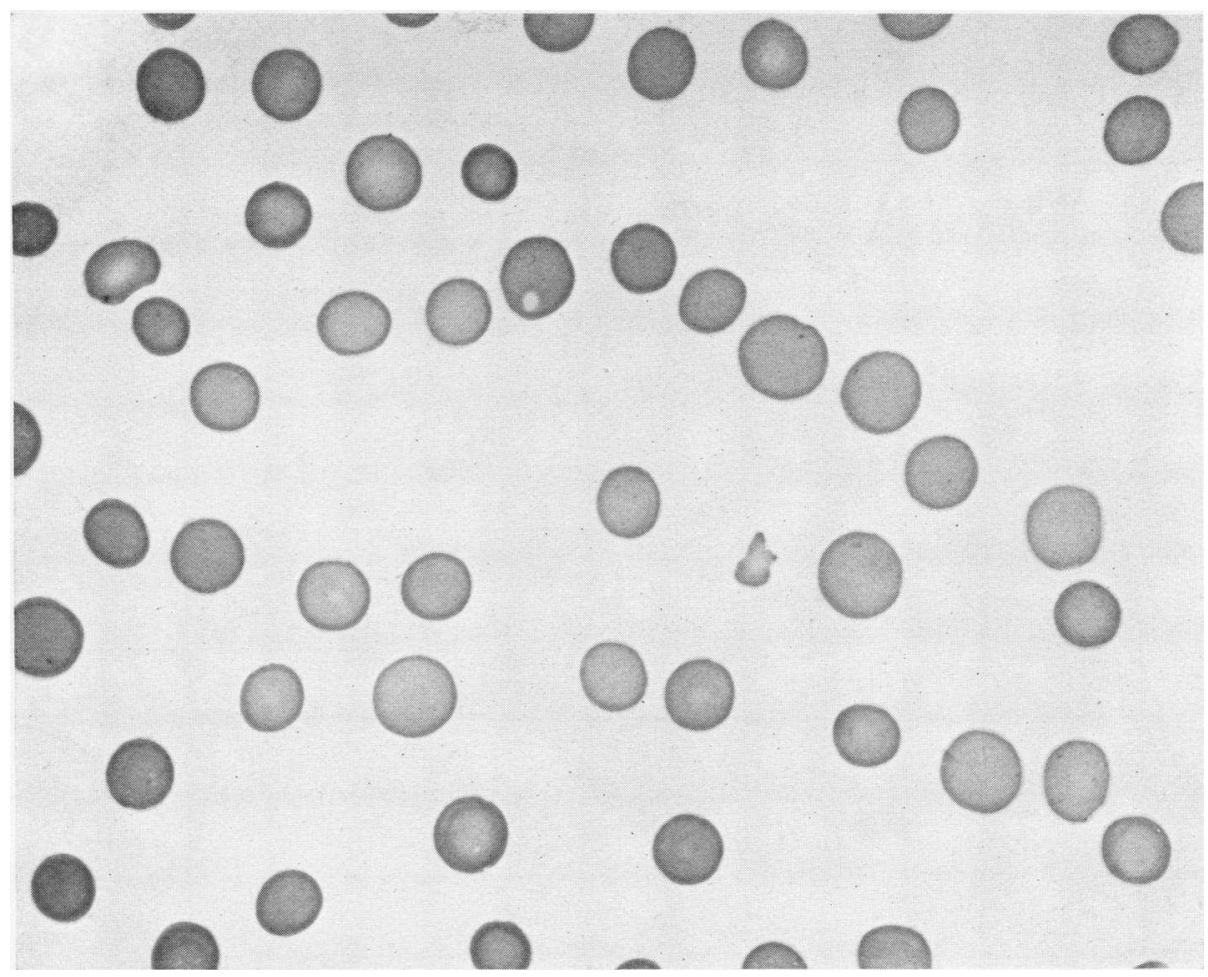

Fig. 5. Photomicrograph of the Blood of Subject Number 1 at the Time of Maximal Axemia. $\times 774$. Wright's Stain.

Impairment of vibratory sensation, which was always preceded by paresthesias, occurred to some degree in the lower extremities of all patients. Decrease in the duration of the perception was the first change noticed. This gradually progressed until, in some instances, the sense of vibration was temporarily lost: first in the great toe, and, in certain subjects, in all the toes and over the malleoli and tibiae.

\section{Gastric acidity and rate of secretion}

No characteristic change in gastric acidity developed in either group. In 3 individuals of Group $I$ it decreased, in 3 it increased and in 2 no change occurred (for details see protocols). The rate of secretion was quite constant, the average figure for all subjects being $44 \mathrm{cc}$. per hour both before and after therapy.

\section{Response to therapy}

The administration of brewer's yeast or liver extract produced relief from all characteristic changes observed (Figures 1, 2, 3). No sig- nificant difference in the effectiveness of these two therapeutic agents was noticed. The percentage of reticulocytes decreased promptly to a level below that observed at any time during the preceding period of observation, and other young forms disappeared from the blood. In some subjects the decline in reticulocytes was preceded by a brief rise, the maximal count observed being 5.6 per cent. The mean corpuscular volume and the mean corpuscular hemoglobin declined steadily; the red cells and the total hemoglobin increased. The blood values returned most nearly to normal in those subjects who received the longest course of therapy. An independent increase in total hemoglobin occasionally took place before yeast or liver therapy was begun; this was attributed to the administration of iron with the diet.

The clinical disturbances also responded promptly to therapy (Table V). Improvement in lingual changes and freedom from fatigue were the first effects noticed, on the average, 14 days after therapy was begun. In general, the phenomena first to appear were first to disappear. 
Before delivery, all the subjects were free of significant symptoms and physical signs, except for slight impairment of vibratory sense in two subjects and for edema in one.

All subjects were delivered of full term normal infants who have developed normally.

\section{Observations on Group II}

No striking changes were observed in the blood values of Group II (Table VI, Figure 6). In the late months of pregnancy a 7 per cent increase in mean corpuscular volume occurred and occasional macrocytes appeared in the blood smear (Figure 7). Subject 3, whose theoretical requirement of vitamin $B$ had increased more than
TABLE VI

Maximal change in blood values of Group II

\begin{tabular}{|c|c|c|c|c|c|c|c|c|c|c|}
\hline \multirow{2}{*}{$\begin{array}{c}\text { Sub- } \\
\text { ject } \\
\text { num- } \\
\text { ber }\end{array}$} & \multicolumn{5}{|c|}{$\begin{array}{l}\text { Initial blood } \\
\text { values }\end{array}$} & \multicolumn{5}{|c|}{$\begin{array}{l}\text { Blood values at time of } \\
\text { maximal change }\end{array}$} \\
\hline & R. B. & Hgb. & $\begin{array}{l}\text { Hema- } \\
\text { tocrit }\end{array}$ & M. C & $\begin{array}{l}\text { M.C. } \\
\text { Hgb. }\end{array}$ & R. B. & Hgb. & $\begin{array}{l}\text { Hema- } \\
\text { tocrit }\end{array}$ & M. C. & $\begin{array}{l}\text { M. C. } \\
\text { Hgb. }\end{array}$ \\
\hline & $\begin{array}{l}\text { mil- } \\
\text { lions }\end{array}$ & $\begin{array}{c}\text { grams } \\
\text { per } \\
100 \\
c c .\end{array}$ & $\begin{array}{c}\text { vol- } \\
\text { umes } \\
\text { per } \\
\text { cent }\end{array}$ & $\mu^{3}$ & $\underset{10^{-12}}{\operatorname{grams}}$ & $\begin{array}{l}\text { mil- } \\
\text { lions }\end{array}$ & $\begin{array}{c}\text { grams } \\
\text { per } \\
100 \\
\text { cc. }\end{array}$ & \begin{tabular}{|c|} 
vol- \\
umes \\
per \\
cent
\end{tabular} & $\mu^{3}$ & $\underset{10^{-12}}{\stackrel{\text { grams }}{\times}}$ \\
\hline $\begin{array}{l}1 \\
2\end{array}$ & $\begin{array}{l}3.97 \\
4.47\end{array}$ & $\begin{array}{l}13.3 \\
14.2\end{array}$ & $\begin{array}{l}38.7 \\
42.0\end{array}$ & $\begin{array}{l}98 \\
94\end{array}$ & $\begin{array}{l}33.5 \\
31.7\end{array}$ & $\begin{array}{l}3.81 \\
4.56\end{array}$ & $\begin{array}{l}13.4 \\
13.4\end{array}$ & $\begin{array}{l}41.4 \\
45.3\end{array}$ & $\begin{array}{r}109 \\
99\end{array}$ & $\begin{array}{l}35.1 \\
29.3\end{array}$ \\
\hline 3 & 3.82 & 13.2 & 39.9 & 104 & 34.5 & 3.86 & 13.7 & 42.5 & 110 & 35.5 \\
\hline $\begin{array}{l}\text { A ver- } \\
\text { agge }\end{array}$ & 4.09 & 13.6 & 40.2 & 99 & 33.2 & 4.08 & 13.5 & 43.1 & 106 & 33.3 \\
\hline $\begin{array}{c}\text { Per } \\
\text { cent } \\
\text { of } \\
\text { change }\end{array}$ & & & & & & -0.2 & -0.7 & +7.0 & +7.0 & +0.3 \\
\hline
\end{tabular}

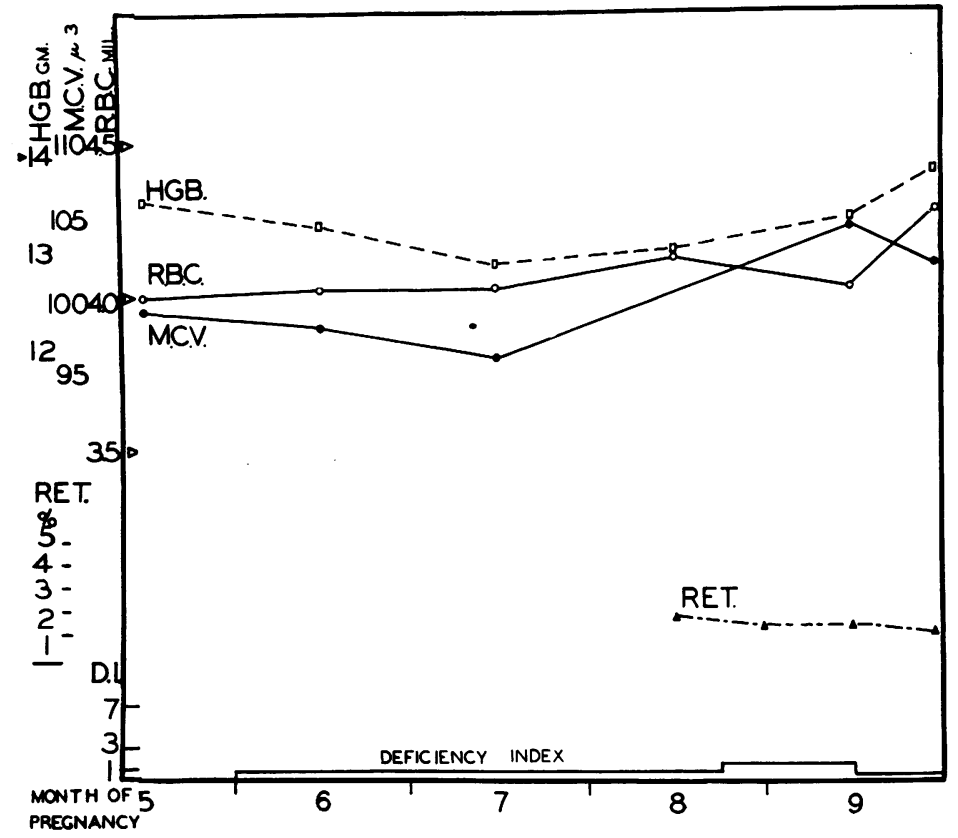

Fig. 6. Average Blood Values of Subjects of Group II.

that of other members of the group, developed sore tongue and paresthesias, clinical disturbances similar to the earliest shown by the subjects of Group I. Both the clinical disturbances and the blood changes in this woman responded promptly to the administration of brewer's yeast. It must be concluded that the diet of this individual, though theoretically adequate, failed in the last months of pregnancy to meet entirely the increased requirement of vitamin $B$. This suggests that the optimum requirement is, in some in- stances, greater than that indicated by the theoretical calculations.

\section{DISCUSSION}

The changes in the blood observed in Group I were characteristic of those known to exist when the bone marrow is hyperplastic, viz., moderate anemia, associated with the presence of immature cells. A substance necessary for normal bone marrow activity, lacking in the habitual diet, was supplied by yeast or by liver extract. That the 
return toward normal blood values was dependent upon the administration of that substance and was not a spontaneous improvement, such as sometimes occurs late in the microcytic anemia of pregnancy (13), is shown by the fact that improvement took place only after therapy was begun, regardless of the time in pregnancy, and that acteristically seen in pernicious anemia, sprue, tropical macrocytic anemia, pernicious anemia of pregnancy and the mild macrocytic anemia of pregnancy observed by Strauss and Castle. In the present observations these changes took place during a period when the intake of food containing vitamin $\mathrm{B}$ was inadequate and were relieved

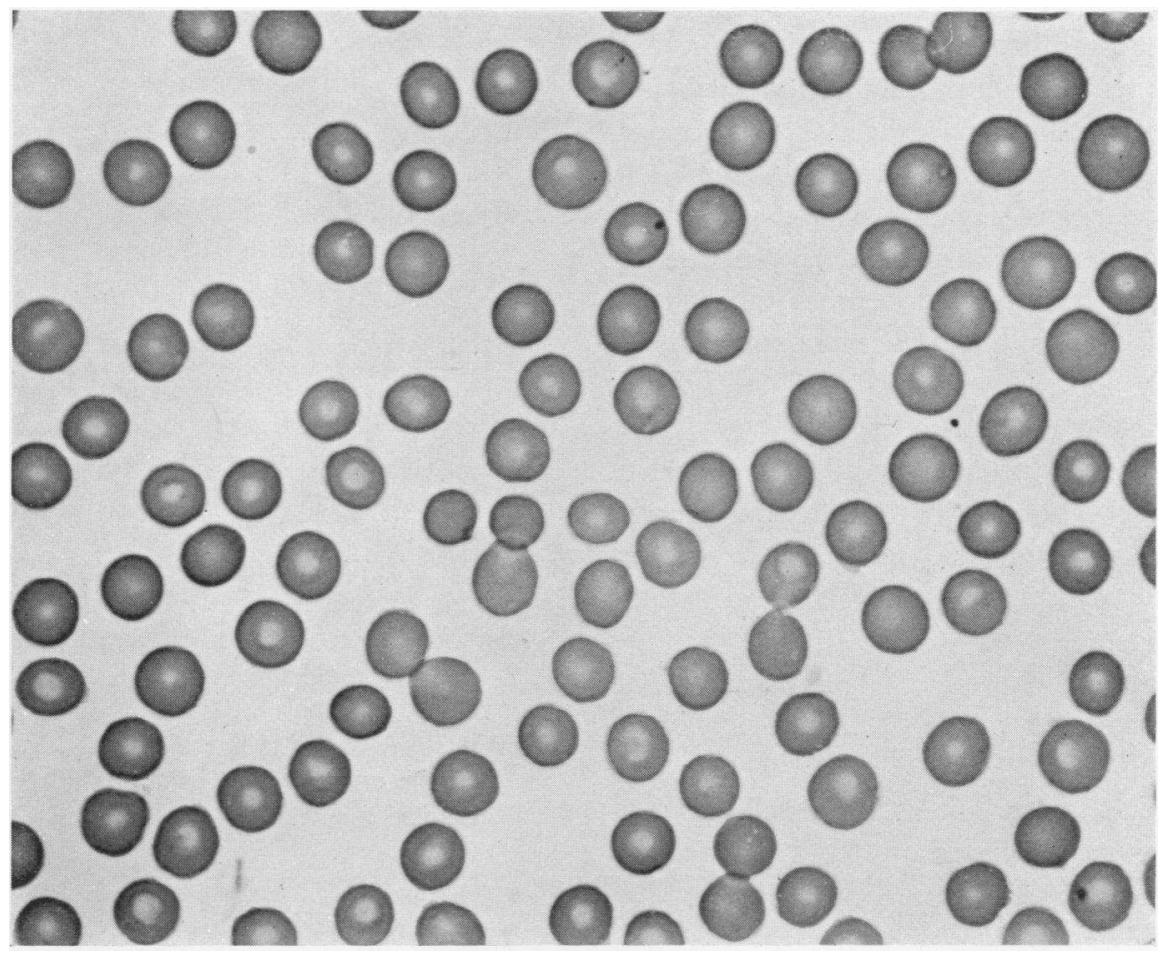

Fig. 7. Photomicrograph of the Blood of Subject Number 2 of Group II. $\times 774$. Wright's Stain.

the return toward normal was greatest in those subjects who received the longest course of therapy.

The clinical disturbances in the subjects of Group I formed a characteristic syndrome involving chiefly the gastro-intestinal tract and the nervous system and were similar to those observed in a previous study of clinical vitamin B deficiency (9). The individual variation in intensity of these manifestations was interesting and suggests either that minor changes in the diet or environment or individual differences in susceptibility may alter considerably the manifestations of a given deficiency.

Both the clinical disturbances and the alterations in blood values were analogous to those char- by therapeutic agents known to be rich in vitamin B. Further identification of the substance responsible for the changes noticed must remain incomplete until various factors now grouped together as vitamin $\mathrm{B}$ are identified and separately tested.

It is interesting to observe that the entire syndrome occurred without consistent change in gastric acidity. This suggests that, while altered gastric secretion of acid may be a late result of deficiency, it is not the cause of the syndrome.

The close correlation of a calculated deficiency in vitamin $B$ with the actual deficiency suggests that the formula of Cowgill indicates approximately the sufficiency of the diet in vitamin B. The vitamin $B$ requirement appears to increase 
during pregnancy with gain in weight in accordance with this formula, a fact, which as demonstrated by the present study, has suggested the important inference that a diet, adequate in vita$\min B$ at the outset of pregnancy, may fail to meet the increased demand for that vitamin late in pregnancy.

\section{SUM M ARY}

1. Characteristic hematological changes and clinical phenomena which developed in 8 pregnant women have been related to a diet adequate except for the amount of vitamin B which it contained.

2. The blood changes were: decrease in number of erythrocytes, increase in mean corpuscular volume and mean corpuscular hemoglobin, macrocytosis, reticulocytosis, the appearance in the blood smear of many polychromatic cells, of poikilocytes and of immature white cells.

3. The clinical disturbances encountered were: glossitis and ulceration of the tongue, impairment or loss of vibratory sense, tachycardia, edema, gastro-intestinal symptoms, easily induced fatigue and paresthesias.

4. The blood and clinical changes responded to brewer's yeast orally or to liver extract intramuscularly.

5. The clinical disturbances appeared, in general, when calculations based on Cowgill's formula indicated a deficiency in vitamin $\mathrm{B}$.

I am indebted to the members of the Obstetrical Staffs and of the Social Service Departments of the Pennsylvania Lying-In Hospital and of this hospital for their cooperation. I am indebted also to members of the Edward B. Robinette Foundation for their assistance in taking electrocardiograms and orthodiagrams and to Dr. J. Harold Austin for his aid in preparation of the manuscript. The assistance of Miss I. M. Dworak, of the Dietetic Division of this hospital, in calculating the dietary requirements of the subjects is gratefully acknowledged.

\section{BIBLIOGRAPHY}

1. Castle, W. B., Rhoads, C. P., Lawson, H. A., and Payne, G. C., Etiology and treatment of sprue. Observations on patients in Puerto Rico and subsequent experiments on animals. Arch. Int. Med., 1935, 56, 627.

2. Strauss, M. B., and Castle, W. B., The nature of the extrinsic factor of the deficiency state in pernicious anemia and in related macrocytic anemias. New England J. Med., 1932, 207, 55.

3. Wills, L., Treatment of pernicious anemia of preg- nancy and tropical anemia, with special reference to yeast extract as curative agent. Brit. M. J., 1931, 1, 1059.

4. Wills, L., and Mehta, M. M., Studies in the pernicious anemia of pregnancy. Indian J. M. Research, 1930, 17, 177.

5. Miller, D. K., and Rhoads, C. P., The experimental production of loss of hematopoietic elements of the gastric secretion and of the liver in swine with achlorhydria and anemia. J. Clin. Invest., 1935, 14, 153.

6. Wills, L., and Stewart, A., Experimental anemia in monkeys with special reference to macrocytic nutritional anemia. . Brit. J. Exper. Path., 1935, 16, 444.

7. Spies, T. D., and Dowling, A. S., The experimental production of anemia in dogs by means of a blacktongue-producing diet. Am. J. Physiol., 1935, 114, 25.

8. Strauss, M. B., and Castle, W. B., Studlies of anemia in pregnancy; etiologic relationship of gastric secretory defects and dietary deficiency to hypochromic and macrocytic (pernicious) anemias of pregnancy and treatment of these conditions. Am. J. M. Sc., 1933, 185, 539.

9. Elsom, K. O'S., Experimental study of clinical vitamin B deficiency. J. Clin. Invest., 1935, 14, 40.

10. Stadie, W. C., A method for the determination of methemoglobin in blood. J. Biol. Chem., 1920, 41, 237.

11. Wintrobe, M. M., The size and hemoglobin content of the erythrocyte. Methods of determination and clinical application. J. Lab. and Clin. Med., 1931$32,17,899$.

12. Cowgill, G. R., The vitamin B requirement of man. Yale University Press, New Haven, 1934.

13. Strauss, M. B., and Castle, W. B., Studies of anemia in pregnancy. II. The relationship of dietary deficiency and gastric secretion to blood formation during pregnancy. Am. J. M. Sc., 1932, 184, 663.

\section{TYPICAL PROTOCOLS OF GROUP I}

(Observations recorded in these protocols are those made at the beginning of the period of observation, shortly before therapy was begun, and afterward. The abbreviations used are as follows : $\mathrm{P}=$ Pulse ; $\mathrm{BP}=$ Blood pressure $\mathrm{RBC}=$ Red blood cells (million); $\mathrm{Hgb}=$ Hemoglobin (grams per $100 \mathrm{cc}$. of blood) ; Hemcrt $=$ Hematocrit (volumes per cent) ; $\mathrm{MCV}=$ Mean corpuscular volume (cubic micra); $\mathrm{MCHgb}=$ Mean corpuscular hemoglobin $\left(\right.$ grams $\left.\times 10^{-12}\right) ; \mathrm{EKG}=$ Electrocardiogram; Ret $=$ Reticulocytes (per cent) ; T.A. == Total gastric acid (cc. 0.1 normal $\mathrm{HCl})$. 
Subject 7 (D. P.): 21 years; para $O$

December 19, 1934: Original observations on subject 62 days pregnant. No symptoms, physical examination normal. P 88; BP 116/72. Gastric analysis-Fasting contents: cc. of juice per hour 20; free $\mathrm{HCl} \mathrm{56,} \mathrm{T.A.} 60$; 40 minutes after alcohol: free $\mathrm{HCl} 48$, T.A. 58. RBC 4.00; Hgb 13.5; Hemcrt 39.7; MCV 99; MCHgb 34.

June 7, 1935: Painful ulcers of the tongue have developed and several of them have coalesced into one which involves most of the dorsum. This large ulcer is shallow, the base is red, and the edges are white. Similar ulcers of the angles of the mouth are present. Vomiting occasionally, and intermittent diarrhea is present. Vibratory sensation is impaired over all the toes. Moderate edema over the tibiae. Complains of dysphagia, burning in the esophagus, epigastric distress after eating and abdominal cramps. Appetite is very poor. Tires easily. P 88; BP 110/74. EKG: unstable rate. Gastric analysis-Fasting contents: cc. of juice per hour 40; free $\mathrm{HCl} 54$, T.A. 60; 40 minutes after alcohol: free $\mathrm{HCl} \mathrm{44,} \mathrm{T.A.}$ 50. RBC 2.81; Hgb 11.3; Hemcrt 34.7; Ret 2.1; MCV 124; MCHgb 40; macrocytosis, occasional megalocytes, polychromasia, occasional poikilocytes.

June 9: Liver extract, 2 cc., given intramuscularly, to be continued for the remainder of observation. June 13: Ret 3.1. June 18: Ret 5.4. June 22 : Ret 0.1 .

June 25: During the last 17 days has received 2 cc. of liver extract intramuscularly daily. Except for slight continued anorexia is without symptoms and considers herself perfectly well. Ulcers of the tongue and lips are entirely healed, vibratory sense is normal, no edema. P 120; BP 122/88. EKG: unstable rate. Gastric analysis -Fasting contents : cc. of juice per hour 52 , free $\mathrm{HCl} 30$, T.A. 36; 40 minutes after alcohol: free HCl 42, T.A. 58. RBC 3.45; Hgb 11.6; Hemcrt 36.7; Ret 0.1; MCV 106; MCHgb 34. The blood is normal in appearance, except for a moderate number of macrocytes. The administration of liver extract is discontinued and brewer's yeast is to be taken orally until delivery.

July 25: Delivered of a full term normal male infant weighing 8 pounds and 15 ounces.
Subject 3 (E. C.): 19 years; para $O$

January 27, 1935: Original observations on subject 112 days pregnant. No symptoms; physical examination is negative. P 72; BP 106/76. Gastric analysis-Fasting contents: cc. of juice per hour 60 , free $\mathrm{HCl} \mathrm{0,} \mathrm{T.A.} \mathrm{18;} 40$ minutes after alcohol: free $\mathrm{HCl} 12$, T.A. 32. RBC 4.74; Hgb 13.2; Hemcrt 41.2; MCV 93; MCHgb 28.

April 13: The tongue is smooth and red. Vibratory sense is normal, there is slight edema over the tibiae. Complains of dysphagia, of marked heartburn and of epigastric distress after eating. Appetite is very poor. Constipation is marked. Intermittent abdominal cramps. Severe paresthesias and cramps in the legs. Tires very easily. P 112; BP 106/68. EKG: unstable rate. Gastric analysis-Fasting contents: cc. of juice per hour 36, free $\mathrm{HCl} \mathrm{0,} \mathrm{T.A.} \mathrm{6;} 40$ minutes after alcohol: free $\mathrm{HCl} 2$, T.A. 8; excessive mucus in all specimens. RBC 3.87; Hgb 14.0; Hemcrt 45.3; Ret 2.1; MCV 117; MCHgb 36.2; macrocytosis, polychromasia, occasional poikilocytes. The administration of 21 grams of brewer's yeast daily is begun. April 20: Ret 2.6. May 5: Ret 1.9.

May 18: Except for mild heartburn is without symptoms and considers herself perfectly well. The tongue is still redder than normal but the papillae have regenerated. Vibratory sense is normal. No edema. P 84; BP 102/78. Gastric analysis-Fasting contents: cc. of juice per hour 88 , free $\mathrm{HCl} 8$, T.A. 12; 40 minutes after alcohol: free $\mathrm{HCl} 32$, T.A. 40 ; no mucus. RBC 4.65; Hgb 15.6; Hemcrt 47.6; Ret 1.5; MCV 102 ; MCHgb 34. The blood is normal in appearance except for a moderate number of macrocytes.

May 29: Delivered of a full term normal female infant weighing 7 pounds and 2 ounces.

\section{Subject 1 (C. G.): 22 years; para II}

February 11, 1935: Original observations on subject 82 days pregnant. Slight dysphagia, physical examination negative. $P$ 84; BP 106/64. Gastric analysis-Fasting contents: cc. of juice per hour 68 , free $\mathrm{HCl} 16$, T.A. $44 ; 40$ minutes after alcohol: free $\mathrm{HCl} \mathrm{4,} \mathrm{T.A.} 18$. RBC 3.65; Hgb 13.0; Hemcrt 38.0; MCV 104; $\mathrm{MCHgb} 36$.

April 15: The tongue is smooth, red and pain- 
ful. History of alternating constipation and diarrhea. Vibratory sense is lost over the great toes and impaired elsewhere in the lower extremities. Edema is moderate over the tibiae. Complains of marked dysphagia and heartburn. The appetite is poor and epigastric distress occurs after eating. Severe paresthesias and cramps in the lower extremities. Tires easily. P 100; BP 114/84. Gastric analysis-Fasting contents: cc. of juice per hour 20, free $\mathrm{HCl} \mathrm{38,} \mathrm{T.A.} \mathrm{58;} 40$ minutes after alcohol: free $\mathrm{HCl} 26$, T.A. 36 . RBC 3.01; Hgb 11.3; Hemcrt 37.4; Ret 4.0; MCV 124; MCHgb 38; macrocytosis, frequent megalocytes, occasional poikilocytes, moderate polychromasia. The administration of 21 grams of brewer's yeast daily is begun. April 22: Ret 5.4. April 27 : Ret 5.1. May 4: Ret 2.8. May 15 : Ret 2.5 .

May 20: Slight anorexia and occasional diarrhea, otherwise free of symptoms. The tongue is normal in appearance. Vibratory sense is normal. Slight edema. P 88; BP 116/78. Gastric analysis-Fasting contents: cc. of juice per hour 52, free $\mathrm{HCl}$ 8, T.A. 16; 40 minutes after alcohol : free $\mathrm{HCl}$ 28, T.A. 38. RBC 3.36; Hgb 11.7; Hemcrt 38.6; MCV 115; MCHgb 35. There are occasional macrocytes, poikilocytes and some polychromatic cells.

May 29: Delivered of a full term normal female infant weighing 7 pounds and 3 ounces. 